EWA KuBIAK

Katedra Historii Sztuki

Uniwersytetu Łódzkiego

\title{
RZECZ NIE TYLKO O ARCHITEKTURZE BUENOS AIRES - „EUROPEJSKIE” MIASTO AMERYKI POŁUDNIOWEJ
}

B uenos Aires do dziś jest miejscem otoczonym aurą tajemnicy i przesyconym duchem dekadencji, a już na pewno można tak określić miasto funkcjonujące na przełomie XIX i XX w. Z perspektywy europejskiej w pewnym okresie postrzegano je jako „ziemię obiecaną” - nieznaną, daleką, ale dzięki temu jeszcze bardziej pociągającą i pożądaną. A przecież wiadomo, że samo określenie „ziemia obiecana” w stosunku do wykluwającej się, przepoczwarzającej i nowo-nowoczesnej (na miarę końca XIX w.) metropolii może być wieloznaczne i niekonieczne pozytywne ${ }^{1}$. Dla Polaków jednym z ważniejszych spotkań z amerykańską metropolią jest lektura Trans-Atlantyku i Dzienników², a może i Wędrówek po Argentynie Witolda Gombrowicza ${ }^{3}$.

${ }^{1}$ Oczywistą konsekwencją wydaje się zatem uzupełnienie tej wizji niepewnego szczęścia przez historię Diny - żydowskiej prostytutki więzionej przez sutenera w jednym z domów publicznych Buenos Aires. Książka El infierno prometido (Piekło obiecane) to typowa historia z ówczesnego Buenos Aires, zaskakujące jest zakończenie - ucieczka „z piekła”, proces, wyzwolenie i nowe życie. Tak naprawdę Elsa Drucaroff, opisując losy dziewczyny, nie wskazuje rzeczywistości na dwóch biegunach, lecz pulsujące, przeplatające się zjawiska żyjącej metropolii przełomu wieków, dualizm świata el fin de siècle i początku XX stulecia (eadem, Piekło obiecane, Kraków 2010; I. Vincent, Ciała i dusze, Wrocław 2006).

${ }^{2}$ Jest to już obraz Buenos Aires końca lat trzydziestych i początku lat czterdziestych XX w. (Trans-Atlantyk) oraz dwóch kolejnych dekad (Dziennik); miasta trochę „okrzepniętego", ale nadal wrzącego, obserwowanego $\mathrm{z}$ uwagą w jego zagęszczeniu zjawisk, a dzienniki, reportersko-osobiste zapiski ludzkiego życia, to - jak określa W. Gombrowicz - „choćby przyozdobione a nawet skłamane - ale tak czy owak, to rosół na smaku rzeczywistości” (idem, Dziennik 1953-1969, Kraków 2011, s. 433).

${ }^{3}$ Poznanie twórczości W. Gombrowicza również dla sporej części Argentyńczyków pozostaje ważnym doświadczeniem. Jego postać, kojarzona z Polską i polskością, wciąż obecna jest w „wyższych sferach” i wywarła niewątpliwy wpływ na niektórych intelektualistów - porteños - przyjaciół z młodości. 
Pewne cechy dookreślające południowoamerykańską rzeczywistość Argentyny pozostają stałe, tak na przełomie wieków, jak i w latach pięćdziesiątych i sześćdziesiątych, kiedy pisarz wiódł życie emigranta-wygnańca, zawieszony między tamtejszą Polonią i miejscową społecznością, nigdzie nie mogąc odnaleźć dla siebie miejsca. Wspomina Argentynę i Buenos Aires:

Argentyna, choć geograficznie gdzieś w zapadłej dziurze zapodziana, utopiona między oceanami, jest w rzeczywistości miejscem otwartym na świat, międzynarodowym, marynarskim, interkontynentalnym... ${ }^{4}$.

Buenos Aires [...] oszalały ruch wehikułów w centrum wielomilionowego olbrzyma, owe zatory, rosnące $\mathrm{w}$ ciągu minuty $\mathrm{w}$ dziesiątki, w setki aut - i tłok ludzki, zabójczy, na chodnikach, w tramwajach, omnibusach, restauracjach, kinach, ta wojna o miejsce wybuchająca przy każdej sposobności. O 7-mej i o 9-tej wieczór czterdzieści do pięćdziesięciu kin skupionych na niewielkiej przestrzeni wymiotuje tłumy zalewające jezdnię i unieruchamiające pojazdy. Neony oślepiają. Feeryczne wystawy sklepowe, nieraz ruchome, kręcące się jak karuzela lub też ukazujące po kolei kilka pięter, stanowią główne oświetlenie ulic jak wąwozy pośród domów dziesięcio-, nieraz dwudziestopiętrowych ${ }^{5}$.

Wracając jednak do początków tego ogromnego centro urbano - wiek XIX oraz przełom XIX i XX stulecia, biorąc pod uwagę rozwój urbanistyczny miasta, był czasem niezwykłym dla Buenos Aires. Metropolia może służyć jako przykład błyskawicznej transformacji. W bardzo szybkim tempie wzrastało zaludnienie: w 1800 r. miasto liczyło 34 tys. mieszkańców, w roku 1869 - 174 tys., a na przełomie wieków już blisko $1 \mathrm{mln}^{6}$. Około 1914 r. zaś liczba mieszkańców miasta przekroczyła 1,5 $\mathrm{mln}^{7}$.

Projekty teoretyczne przemian urbanistycznych zakładały całkowite zerwanie z tradycją kolonialną, a więc przestarzałą i niepotrzebną w nowo kreowanym świecie. Na szkicu z 1828 r. autorstwa Santiago Bevansa, ukazującym plany przebudowy miasta, widoczna jest zupełna zmiana funkcjonującej dotąd stylistyki kolonialnej. Nowoczesna, często utopijna, wizja struktury miejskiej szokowała ${ }^{8}$, a projekty, które powstawały w pierwszej połowie XIX w., nie doczekały się realizacji. Prawdziwa przebudowa miasta zaczęła się pod koniec stulecia. Osobą odpowiedzialną za znaczne przemiany urbanistyczne był Torcuato Antonio de Alvear y Sáenz de la Quintanilla,

${ }^{4}$ W. Gombrowicz, Wspomnienia polskie. Wędrówki po Argentynie, Kraków 2011, s. 233.

${ }^{5}$ Ibidem, s. 305-306.

${ }^{6}$ R. Gutiérrez, Arquirectura y urbanismo en Iberoamerica, wyd. 4, Madrid 2002, s. 529.

7 R. Stemplowski, Stabilizacja i rozwój zależny (1870/1880-1910/1918). Kraje La Platy, [w:] Dzieje Ameryki Łacińskiej 1870/1880-1929, t. 2, red. R. Mroziewicz, R. Stemplowski, Warszawa 1979, s. 151.

${ }^{8}$ R. Gutiérrez, op. cit., s. 529. 
zarządzający miastem w latach 1880-1887. Dominującym i wszechobecnym modelem dla Buenos Aires pozostawał Paryż. Projekty realizowane w stolicy Francji docierały do Argentyny i tu niemal dosłownie powtarzane były ich fragmenty. Jednak trzeba pamiętać, że architektoniczne „cytaty” to bardziej parafrazy i wariacje na temat oryginalnych konstrukcji niż „literalna transkrypcja”. Avenida de Mayo - główna arteria nowoczesnego Buenos Aires przypomina paryską Rue Reamur. W szkołach uczono dzieci od najmłodszych lat, że Buenos Aires jest stolicą Ameryki, a Paryż stolicą świata ${ }^{10}$.
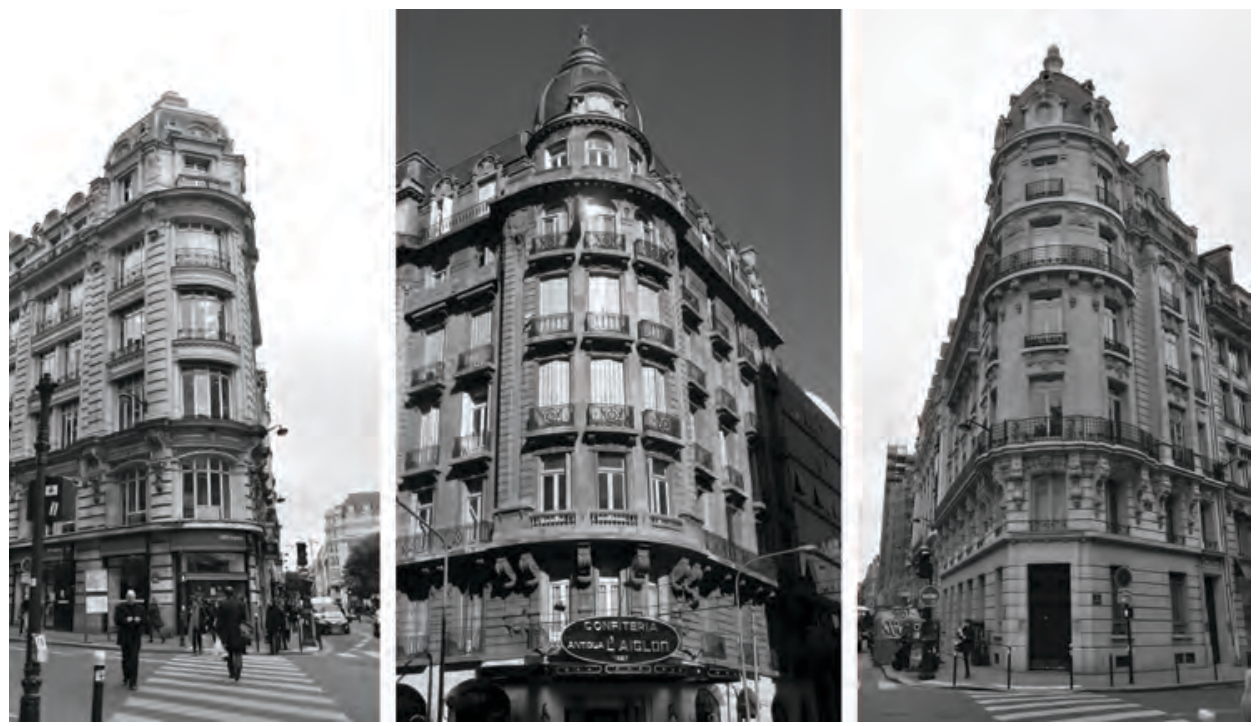

Ryc. 57. Kamienica na rogu Rue Réamur i Rue Monmartre, Paryż; budynek przy Avenida Callao 98, Buenos Aires; kamienica na przeciwległym narożniku Rue Réamur i Rue Monmartre, Paryż, 2013

W „La Géographie” z 1907 r. możemy przeczytać relację mówiącą o tym, że po długiej morskiej podróży przybywający z Francji turysta odnajduje miasto o przyjaznym, umiarkowanym klimacie, z podobną do rodzimej kulturą i architekturą, a na ulicach spotkać może wielu mieszkańców mówiących płynnie po francusku¹. Jak pisze Ryszard Stemplowski:

Elita argentyńska czuła się związana z Europą. Z Europy pochodziła znaczna część ludności, zacieśniały się więzy gospodarcze z Wielką Brytanią, Niemcami, Francją i Belgią, europejska (głównie francuska) była formacja

9 J.D. Needell, Rio de Janeiro and Buenos Aires: Public Space and Public Consciousness in Fin-DeSiècle Latin America, „Comparative Studies in Society and History”, lipiec 1995, t. 37, nr 3, s. 521.

${ }^{10}$ R. Gutiérrez, op. cit., s. 409.

11 J.P. Daughton, When Argentina Was „French”: Rethinking Cultural Politics and European Imperialism in Belle-Époque Bienos Aires, „The Journal of Modern History”, grudzień 2008, nr 80, s. 837. 
intelektualna elity, uświadamiano sobie swą inność („wyższość”) w stosunku do południowoamerykańskiego otoczenia ${ }^{12}$.

Buenos Aires było typowym miastem przełomu wieków, miało wyraźnie „europejski” charakter, co do dziś jest mocno odczuwalne. Fasady kamienic, struktury rezydencji przypominają paryską zabudowę, a fragmenty ulic wydają się być przeniesione z francuskiej stolicy. „Europeizację” metropolii możemy zaobserwować w urbanistyce miasta, organizacji ulic i placów, w szacie architektonicznej poszczególnych budynków, co związane było zarówno z ogólnie panującą modą i tendencjami artystycznymi, jak i pochodzeniem twórców, a także przemianami społeczno-politycznymi na terenie całego kraju.

Ważnym czynnikiem wpływającym na zmianę upodobań architektonicznych były historyczne losy Argentyny. Wicekrólestwo La Platy ze stolicą w Buenos Aires wyodrębniono dość późno - rząd madrycki podjął decyzję o powstaniu nowej jednostki administracyjnej w 1776 r., wcześniej obszar dzisiejszej Argentyny należał do Wicekrólestwa Peru, a rozwój i kolonizacja tej części Ameryki hamowane były przez mieszkańców ówczesnej stolicy - Limy. Dopiero w ostatniej ćwierci XVIII w. sytuacja uległa zmianie. W skład ziem nowego wicekrólestwa weszła dzisiejsza Boliwia, północne Chile, Paragwaj, Urugwaj i Argentyna. Po tych zmianach Buenos Aires jako miasto portowe rozwijało się bardzo szybko - stało się najważniejszym pośrednikiem w handlu z Europą, ale i ośrodkiem ciemnych interesów, zyskując sławę przemytniczego centrum w zakresie przeróżnych towarów. Po zmianach terytorialnych to właśnie stąd wywożono do Starego Świata srebro z kopalni w Potosí, a także skóry bydlęce - początkowo były to dwa podstawowe produkty eksportowe. Natomiast z Europy importowano już nie tylko towary luksusowe, ale i tańsze - przez 30 lat Buenos Aires żyło z handlu, zalewając lokalny rynek wy robami europejskimi, co hamowało rozwój miejscowego rzemiosła i przemysłu ${ }^{13}$. Wiek XIX był okresem przemian, które prowadziły do ustanowienia niepodległości amerykańskich kolonii. W dniu 9 lipca 1816 r. kongres w Túcuman proklamował niepodległość La Platy ${ }^{14}$, jednak państwo w kolonialnych granicach nie przetrwało. W konstytucji z 1824 r. znalazła się nazwa „Republika Argentyńska”, a koncepcja La Platy kolonialnej zniknęła.

Ważnym elementem rozwoju nowego państwa było zagospodarowanie wybrzeża, wiązało się to z koniecznością zwiększenia zaludnienia

12 R. Stemplowski, op. cit., s. 161-162.

13 J. Szemiński, Schyłek epoki kolonialnej (1750-1800), [w:] Dzieje Ameryki Łacińskiej 1750-1870/1880, t. 1, red. T. Łepkowski, Warszawa 1979, s. 100-101.

${ }^{14}$ T. Łepkowski, Wojny o niepodległość (1801-1825), [w:] Dzieje Ameryki Łacińskiej..., s. 235. 
słabo zasiedlonych terenów. W połowie XIX w. zdano sobie sprawę, że pomimo stosunkowo szybkiego wzrostu liczby ludności niezbędna do rozwoju kraju jest masowa imigracja z Europy. Od 1857 r. rząd argentyński organizował imigracje, jednak największa fala europejskich przybyszów pojawiła się w ostatnich dwóch dekadach XIX w. ${ }^{15}$, na zawsze zmieniając strukturę argentyńskiego społeczeństwa ${ }^{16}$. Buenos Aires jako stolica rozwijało się z impetem, a mieszkańcy miasta (nazywani do dziś porteños) bardzo szybko przystosowywali się do zmiennych warunków gospodarki i potrafili czerpać zyski zarówno z eksportu, importu, jak i - w późniejszym okresie - z rozwoju przemysłu.

Wszystko to znalazło oddźwięk w krajobrazie architektonicznym miasta. W latach 1862-1930 ostatnie pozostałości tradycji kolonialnej (czy też kreolskiej) w architekturze zostały „zduszone” przez nowinki techniczne przywiezione przez europejskich twórców ${ }^{17}$. Koniec XIX w. jest również dalszym okresem negacji wszystkiego, co wiązało się z kolonią, a zatem i Hiszpanią. Zerwanie z przeszłością znalazło odzwierciedlenie w sztuce, przełom wieków charakteryzuje się zwróceniem ku Europie zachodniej - na zawsze zmieniła się kultura, polityka i sztuka Argentyny ${ }^{18}$.

\section{URBANISTYKA}

2 ardzo duży wpływ na przekształcenia urbanistyczne argentyńskiej 13 metropolii wywarły koncepcje Georgesa Eugène’a Baróna Haussmanna. Podobnie jak w Paryżu, rozpoczęto na dużą skalę wyburzanie dawnej zabudowy ${ }^{19}$. Bez żalu niszczono zabytki epoki kolonialnej, negując ich walory artystyczne, zniknęły gmachy konsulatu, Casa de Virreinal, dawny budynek Izby Celnej ${ }^{20}$ - ich historyczność działała raczej negatywnie, były bowiem świadectwem czasów politycznej i gospodarczej zależności, przeciwstawianych wolności i niezależności nowej Argentyny. Od 1884 r. trwały prace nad przekształceniem głównej arterii miasta - Avenida de Mayo - łączącej Plaza de Mayo z Plaza de Lorea ${ }^{21}$. Inicjatorem modernizacji miasta we francuskim stylu był wspomniany już T. de Alvear, a skonkretyzowanie nowego wizerunku stolicy nastąpiło na początku lat osiemdziesiątych XIX w. Pierw-

15 Idem, W poszukiwaniu kształtu niepodległości (1825-1870/80), [w:] Dzieje Ameryki Łacińskiej..., s. 354.

${ }_{16}$ M.C. Eakin, Historia Ameryki Łacińskiej. Zderzenie kultur, Kraków 2007, s. 277.

17 M.J. Buschiazzo, La arquitectura en la Republica Argentina 1810-1930, Buenos Aires 1966, s. 22.

18 Ibidem, s. 24.

19 J.D. Needell, op. cit., s. 521.

${ }^{20}$ M.J. Buschiazzo, op. cit., s. 28.

${ }^{21}$ R. Gutiérrez, op. cit., s. 530. 
szym etapem było przekształcenie głównego placu miasta, Recova Vieja, wyburzono starą zabudowę, a prace nad nowym projektem powierzono Juanowi Antoniowi Buschiazzowi, który stworzył przestrzeń w formach architektonicznych nawiązujących do wzorów francuskich; powstający plac otrzymał nową nazwę - Plaza de Mayo.

Oficjalną decyzję o powstaniu Avenida de Mayo wydano 7 października $1885 \mathrm{r}$. Był to pierwszy bulwar miasta, oś ukształtowana początkowo jako przestrzeń rekreacyjna, po pewnym czasie jednak skupiająca najważniejsze instytucje publiczne ${ }^{22}$. Mimo wielkiego zachwytu „reformami hausmannowskimi” ${ }^{23}$ trzeba zaznaczyć, że w porównaniu z Europą przekształcenia struktury miejskiej w Buenos Aires przeprowadzone zostały w zredukowanej skali. Projekty bardziej globalne pozostały w sferze planów, a ukształtowanie przestrzeni miejskiej było zwykle rezultatem przedsięwzięć „częściowych”, przeprowadzanych zawsze zgodnie z wolą władz miejskich ${ }^{24}$. Inauguracja pierwszej „republikańskiej” alei w Ameryce Południowej, Avenida de Mayo, odbyła się 9 lipca 1894 r. Ulica łączy dwa bardzo istotne punkty miasta - Plaza de Mayo, najważniejszy plac od czasów założenia Buenos Aires, z Plaza de Lorea, na którym w przyszłości stanął budynek Kongresu, a plany wzniesienia gmachu istniały już w momencie powstawania arterii. Urbanistycznym zamierzeniem było zatem połączenie na jednej osi fasad Casa Rosada, czyli pałacu prezydenckiego, i Palacio del Congreso ${ }^{25}$. $\mathrm{Z}$ aleją łączyło się ponad 10 przecznic między placami, jednak ich liczba w efekcie dalszych przekształceń urbanistycznych ulegała zmianie. Formy architektoniczne, jak i struktura bulwaru inspirowana była zabudową Paryża, jednak aleję można też rozumieć jako obraz kosmopolitycznych tendencji charakterystycznych dla Buenos Aires przełomu wieków - architektura ulicy była tak różnorodna, jak społeczność zamieszkująca miasto, oprócz najważniejszych tendencji „francuskich” można zauważyć elementy typowe dla architektury Wielkiej Brytanii, Włoch, a nawet Niemiec. Kształtowanie nowej przestrzeni łączyło się z nowymi funkcjami „ulicy”, co zaobserwować możemy w nowej typologii zabudowy: powstawały kamienice mieszkalne często przeznaczone na wynajem ${ }^{26}, \mathrm{z}$ bardziej luksusowymi apartamentami od frontu i skromniejszymi w głębi ${ }^{27}$, przestrzeniami handlowymi, kawiarniami, klubami, teatrami ${ }^{28}$. Ważnem elementem zabudowy były także hotele wznoszone według nowych standardów; najwyższe kon-

\footnotetext{
22 E. Radovanovic, Buenos Aires. Avenida de Mayo, Buenos Aires 2002, s. 6.

${ }^{23}$ Zob. także: E. Radovanovic, Buenos Aires. Ciudad Moderna 1880-1910, Buenos Aires 2002.

${ }^{24}$ Idem, Buenos Aires. Avenida..., s. 7.

25 M.J. Buschiazzo, op. cit., s. 28.

${ }^{26}$ E. Radovanovic, Buenos Aires. Avenida..., s. 7.

27 L. Aslan, G. Novoa, Buenos Aires: Balvanera, 1817-1970, Buenos Aires 1992, s. 39.

${ }^{28}$ E. Radovanovic, Buenos Aires. Avenida..., s. 7.
} 
strukcje przy Avenida de Mayo pełniły w większości funkcje hotelowe ${ }^{29}$. Projekty uwzględniały nowoczesne aspekty architektury funkcjonalnej, w budownictwie szeroko wprowadzono użycie szkła i metalu. Nowinki inżynierskie pojawiły się także w sferze organizacji transportu miejskiego. Początkowo istniały plany powstania na Avenida de Mayo linii tramwajowej (w Buenos Aires tramwaje zasilane trakcją elektryczną funkcjonowały od 1897 r.), jednak projekt szerokiej, przestrzennej alei wykluczał tę możliwość. Ostatecznie zdecydowano się na budowę metra, które w efekcie połączyło dwa place ${ }^{30}$. Decyzja o budowie pierwszej linii subteterraneo zapadła już w 1903 r., wpływ na nią miał ciągły wzrost liczby mieszkańców i trudności komunikacyjne, z jakimi borykało się miasto. W 1909 r. Kongres uchwalił początek prac, oficjalne otwarcie pierwszej linii miało miejsce 1 grudnia 1913 r., a Buenos Aires stało się pierwszym miastem w Ameryce Łacińskiej (trzynastym na świecie), gdzie zaczęło funkcjonować metro ${ }^{31}$.

\section{ARCHITEKTURA}

S wiadectwem „europeizacji” przestrzeni miejskiej Buenos Aires były nie tylko przeprowadzone reformy urbanistyczne, lecz także formy poszczególnych budowli. Kilka przykładów może zilustrować kosmopolityczne tendencje artystyczne argentyńskiej stolicy - przykładów zupełnie subiektywnych, które są raczej świadectwem miejskich wędrówek niż reprezentatywną syntezą nowej zabudowy miasta, można jednak wśród nich odnaleźć zarówno kilka najbardziej znanych obiektów, jak i „niszowe” budowle, które powstawały od lat osiemdziesiątych XIX stulecia do początku lat trzydziestych XX w.

Jedną z ciekawszych realizacji „nowego Buenos Aires” jest El Palacio de Aguas Corrientes. W 1854 r. rada miejska zdecydowała, że należy podjąć prace związane z poprawą sytuacji sanitarnej miasta. W 1867 r. powstała komisja poprzedzająca kolejną instytucję: Obras Sanitarias de la Nación. Pierwszy obiekt, którego zadaniem było zaopatrywanie miasta w czystą wodę oraz magazynowanie jej, powstał przy placu Lorea, jednak szybki wzrost liczby ludności, jak i terytorialne rozrastanie się terenów zurbanizowanych sprawiło, że potrzebne były rozwiązania bardziej globalne.

El Palacio de Aguas Corrientes prócz niewątpliwie najważniejszej roli z punktu widzenia higieny miasta posiada niezwykle interesujący kostium architektoniczny. Początek budowy obiektu datuje się na rok 1887,

${ }^{29}$ R. Gutiérrez, op. cit., s. 468.

${ }^{30}$ E. Radovanovic, Buenos Aires. Avenida..., s. 7.

${ }^{31}$ Wcześniej metro funkcjonowało m.in. w takich miastach jak: Londyn, Ateny, Wiedeń, Budapeszt, Paryż. 
a projektantami byli szwedzki inżynier Carlos Nystomeyer i norweski architekt Olaf Boye. Mimo jednorodnej stylistyki w duchu francuskiego historyzmu z pewnymi elementami dekoracji o charakterze secesyjnym dzieło można uznać za odzwierciedlenie kosmopolitycznej natury miasta. Wzniesienie samego budynku powierzono miejscowej firmie Rocchi y Cía, ale elementy wykończeniowe pochodziły z Europy. Piękne barwne reliefy o nasyconej kolorystyce dekorujące fasadę wyprodukowano $\mathrm{w}$ fabrykach Royal Doulton \& Co. z Londynu oraz Bourmantofts Company z Leeds; elementy metalowe konstrukcji wykonała belgijska firma Mercinelle et Coulliert, natomiast rzeźby metalowe przedsiębiorstwo Macfarlane \& Co. z Glasgow ${ }^{32}$.

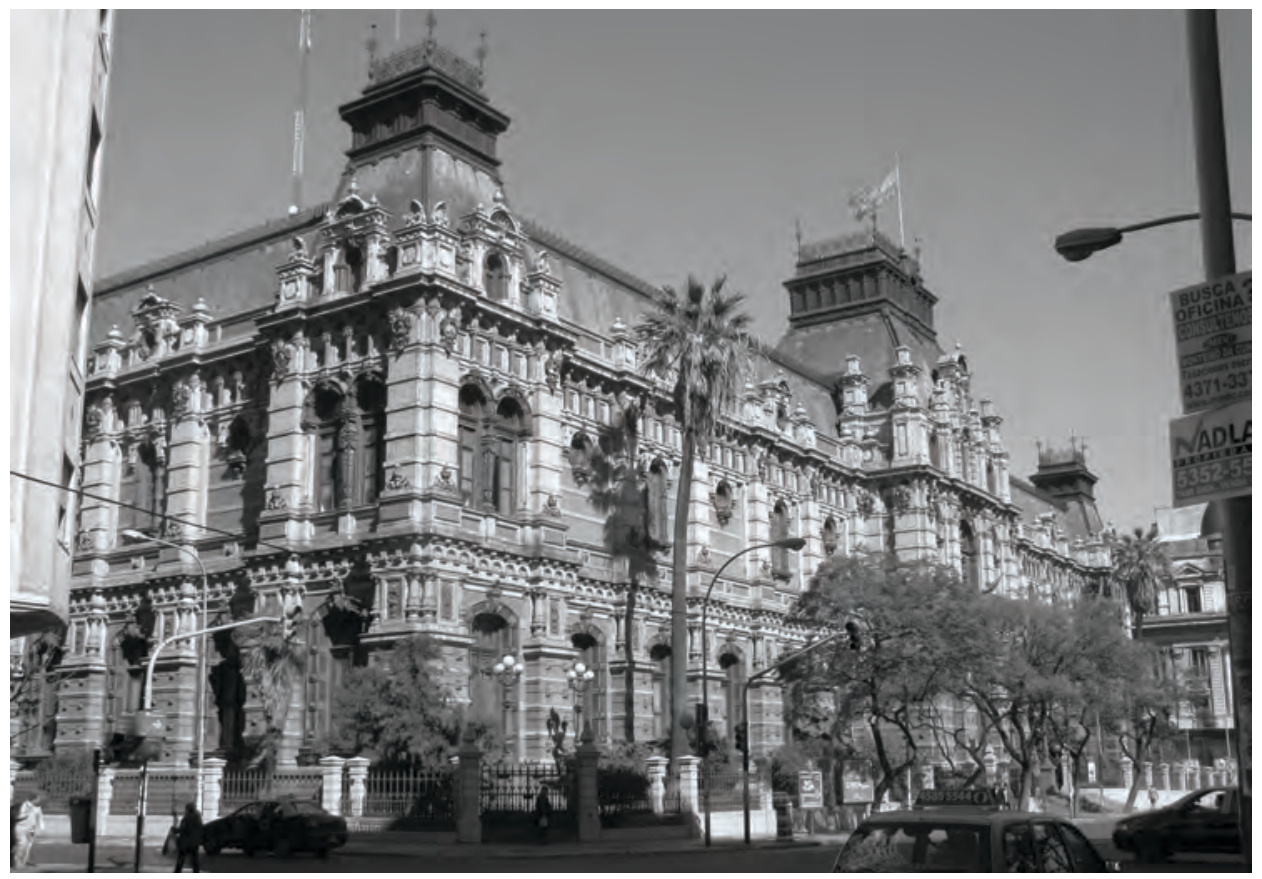

Ryc. 58. Palacio de Aguas Corrientes, 1887-1894, inż. Carlos Nystomeyer, arch. Olaf Boye, Buenos Aires, 2011

Bardzo ciekawym budynkiem pochodzącym mniej więcej z tego samego okresu jest Casa Rosada, czyli siedziba prezydenta Argentyny od czasów sprawowania rządów przez Dominga Faustina Sarmienta. Gmach znajduje się przy Plaza de Mayo, powstał w latach 1882-1898, a architektem kończącym dzieło był Francisco Tamburini. Różowy kolor ścian nie jest przypadkowy, budynek otrzymał taką barwę jako wyraz symbolicznego manifestu

${ }^{32}$ L. Aslan, G. Novoa, op. cit., s. 52-53. 
polityki prezydenckiej, której jednym z osiągnięć było doprowadzenie do zażegnania konfliktu pomiędzy „czerwonymi” federalistami i „białymi” unitarystami. Jednak Casa Rosada nie jest pierwszym budynkiem w tym miejscu, od samego początku istnienia miasta funkcjonowały na tym terenie budowle pełniące funkcje siedziby aktualnej władzy. Najwcześniej znajdował się tutaj fort, czyli Real Fortaleza de Don Juan Baltasar de Austria ${ }^{33}$. Budynki służyły jako siedziba najpierw gubernatorom prowincji, następnie wicekrólom La Platy, a w końcu, już w okresie niepodległości, przedstawicielom rządu. Około 1850 r. zburzono starą zabudowę, a trzy lata później wzniesiono Nową Izbę Celną zaprojektowaną przez angielskiego architekta Edwarda Taylora $^{34}$. W 1878 r. w południowej części założenia D.F. Sarmiento
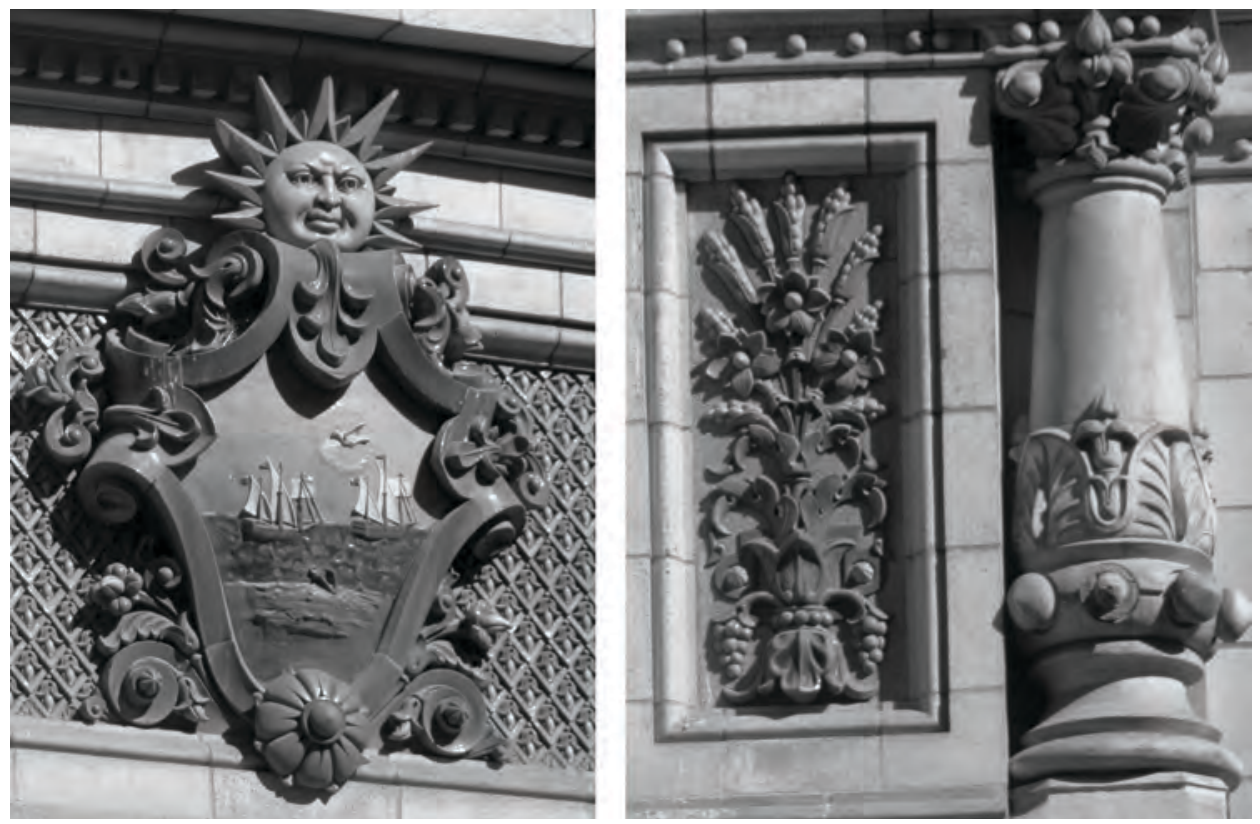

Ryc. 59. Detal fasady Palacio de Aguas Corrientes, 1887-1894, inż. Carlos Nystomeyer, arch. Olaf Boye, Buenos Aires, 2011

zdecydował się zbudować Palacio Correo, a projekt powierzył szwedzkiemu architektowi Karolowi Kihlbergowi. Oba budynki nawiązywały formą do włoskiego renesansu. Prace ciągnęły się bardzo długo, wkrótce okazało się, że rezydencja prezydencka jest zbyt mała i postanowiono o wzniesieniu nowej Casa del Gobierno (wybrano projekt szwedzkiego architekta Enrique

${ }^{33}$ Jego budowa rozpoczęła się w 1594 r., ale prace trwały do początku XVIII w.

${ }^{34}$ H.S.J. Panda, Arquitectura de 1850 a 1850, seria "Arquitectura en Argentina”, t. 7, Buenos Aires 1980, s. 113. 
Aberga) ${ }^{35}$, a następnie na połączenie obu gmachów - i wówczas, w 1883 r., prace powierzono F. Tamburiniemu ${ }^{36}$, który nadał całości szatę eklektyczną $\mathrm{z}$ elementami neorenesansowymi. Budynek był naśladowany w wielu miastach na prowincji Argentyny, gdzie oczywiście założenia realizowano w mniejszej skali, wspomnieć możemy tu siedziby lokalnych władz w Corrientes, Paranie, Catamarce czy w Posadas. Bliskie formami, choć bardziej eklektyczne w duchu, były też późniejsze budowle z Santa Fe, La Platy oraz Jujuy $^{37}$. Ta ostatnia została wzniesiona do 1927 r. przez firmę J. Stramandinoli i synowie według planów architekta Gonzalo A. Correi.
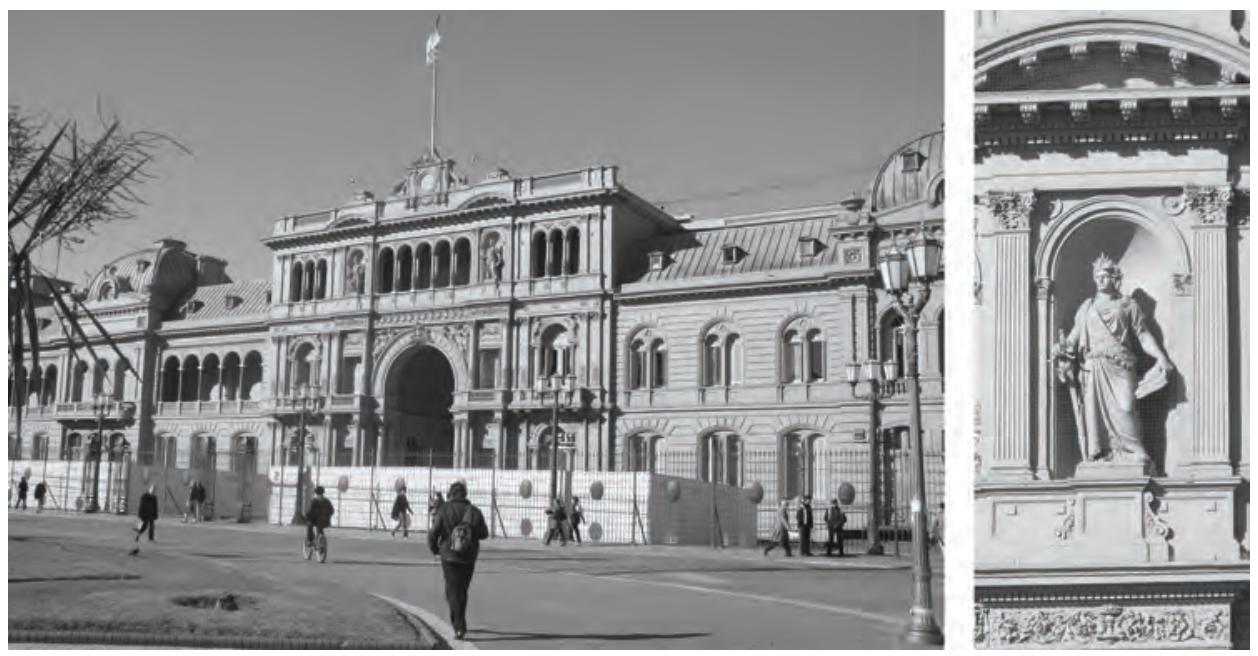

Ryc. 60. Casa Rosada, 1882-1898, arch. Francisco Tamburini, Buenos Aires, 2011

Na przeciwległym krańcu Avenida de Mayo zlokalizowany został inny budynek rządowy - gmach parlamentu, czyli Palacio del Congreso. Pomysł wzniesienia nowej siedziby narodziła się w 1882 r. W dniu 20 lutego 1895 r. ogłoszono międzynarodowy konkurs architektoniczny na gmach parlamentu, a jako ostateczna datę składania projektów ustalono 12 października tego samego roku. Spłynęło 28 prac, m.in. autorstwa architektów francuskich, takich jak Lefebre, Tronchet i Rey, Paul Henry Nenot; włoskich - Sommaruga, Vittorio Meano i Calderini; projekt Austriaka M.A. Turnera; architekta urugwajskiego Vaeza Ocampa (opracowany wspólnie z Alfredem Massue), jak również twórców argentyńskich: Avenattiego, Emilia Agrela, Césara Gonzáleza Segura (współpracującego z Emiliem Mitrem i Francuzem Gustavo Doparkiem), Bernarda Meyera Pellegriniego i wreszcie Norwega

35 F. Ortiz, La arquitectura en la Argentina desde 1880 hasta 1930, seria „Arquitectura en Argentina", t. 8, Buenos Aires 1980, s. 121.

${ }^{36}$ R. Gutiérrez, op. cit., s. 421.

${ }^{37}$ R. Gutiérrez, op. cit., s. 422. 
Alejandra Christophersena. Zdecydowano się na projekt V. Meana, prace rozpoczęły się w 1897 r., a po śmierci architekta (został zamordowany we własnej rezydencji 1 lipca 1904 r.) pracami według oryginalnych projektów kierował Belg Julio Dormal. Inauguracja Palacio del Congreso odbyła się 12 maja 1906 r. Stylistyka budynku określana jest jako eklektyzm grecko-rzymski w nurcie akademizmu włoskiego, charakterystycznego dla V. Meana. Elementem przykuwającym wzrok jest szeroka, horyzontalnie rozciągnięta kolumnada fasady oraz kopuła stanowiąca akcent wertykalny i wyznaczający oś kompozycyjną. Gmach od początku istnienia wzbudzał rozmaite emocje. Anatole France, odwiedzając Buenos Aires w 1909 r., opisał go następującymi słowy:

Mieszanka zawierająca włoską sałatkę z greckimi, rzymskimi i francuskimi ingrediencjami. Na kolumnadzie wziętej z Luwru stawia się Partenon, na Partenonie udało się umieścić Panteon, a cały ten tort obsypać alegoriami, posągami, balustradami i tarasami. To wszystko przywodzi na myśl zamęt podczas wznoszenia wieży Babel ${ }^{38}$.
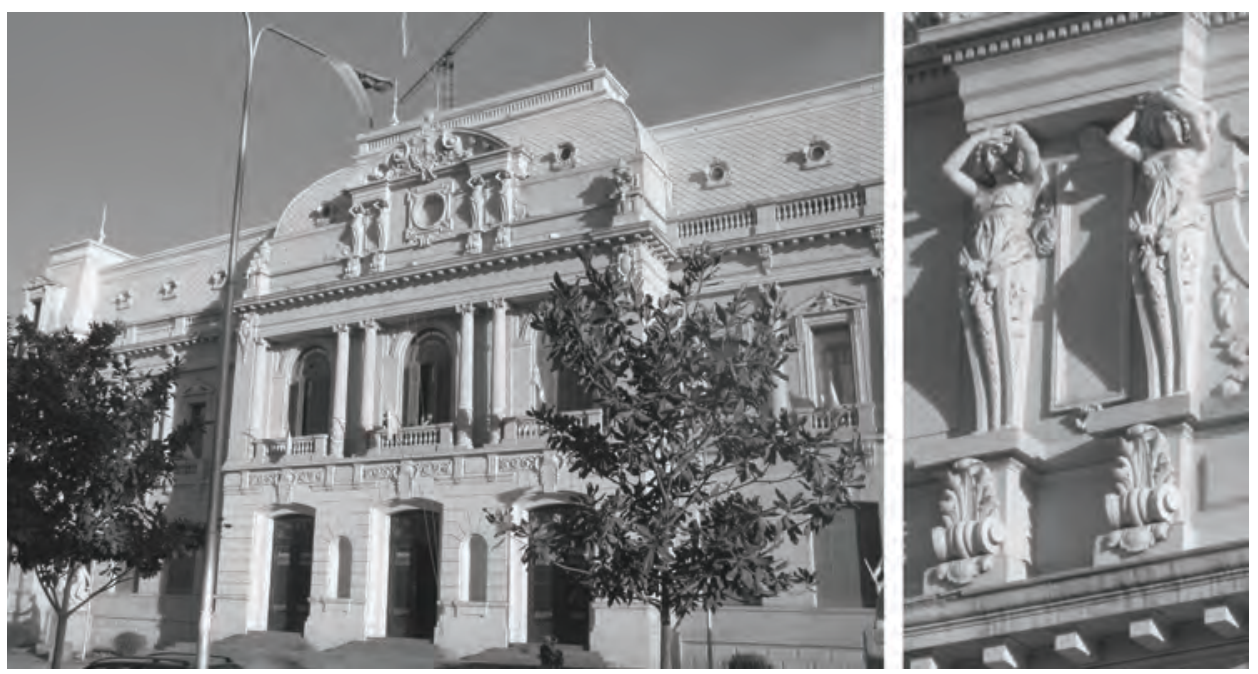

Ryc. 61. Palacio de Gobierno, 1927, arch. Gonzalo A. Correa, Jujuy, Argentyna, 2008

Zadziwiającym natomiast wydaje się (w opracowaniach, w których wymieniany jest gmach argentyńskiego Kongresu) brak odniesienia do budynku waszyngtońskiego Kapitolu, który „opatrzonemu architektonicznie” obserwatorowi natychmiast przychodzi na myśl jako niezaprzeczalna analogia.

${ }^{38}$ Cyt. za: Arquitectura Latinoamericana en el siglo XX, red. R. Gutiérrez, Barcelona 1998, s. 122; R. Gutiérrez, op. cit., s. 424; M.F. Guillén, Modernism without Modernity: The Rise of Modernist Architecture in Mexico, Brazil, and Argentina, 1890-1940, „Latin American Research Review" 2004, t. 39, nr 2, s. 17. 


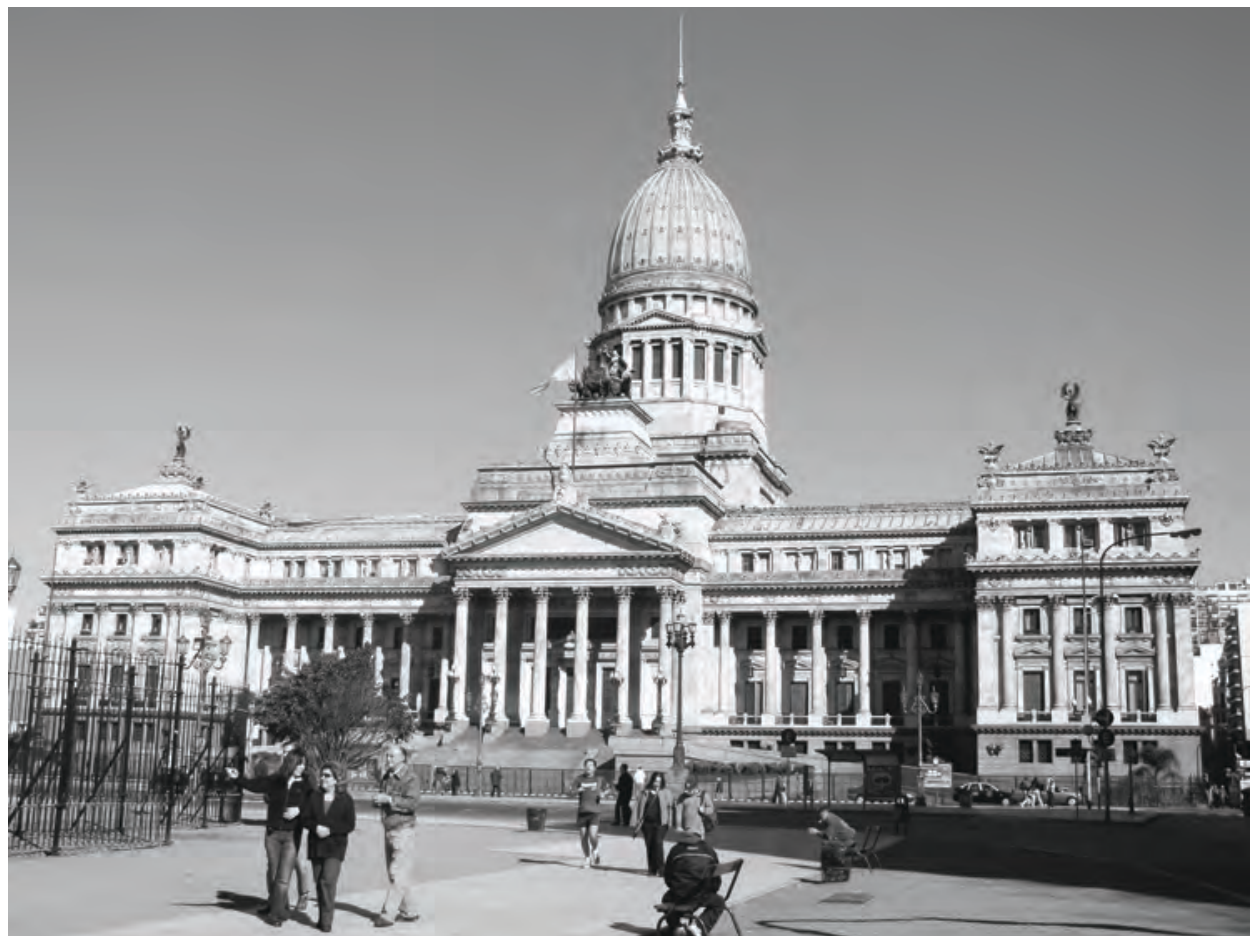

Ryc. 62. Palacio del Congreso, 1897-1906, fasada, arch. Vittorio Meano, 2008

Naprzeciwko gmachu parlamentu, przy Avenida Rivadavia 1801 (na rogu z Avenida Callao), znajduje się inny ciekawy obiekt architektoniczny Buenos Aires - La Confitería del Molino ${ }^{39}$ - który nie tylko zwraca uwagę swoimi niezwykłymi formami, lecz jest też miejscem ważnym historycznie i kulturowo w strukturze życia miejskiego. Kawiarnia w zmodernizowanym budynku została otwarta 9 lipca 1916 r., a zamknięta niedawno, w 1997 r. Historia funkcjonującego tu przedsiębiorstwa związana jest ściśle z włoska emigracją. W 1914 r. firma Antigua Confitería del Molino należała do Gaetana Brenny, który potrzebował nowej siedziby dla swojego rozrastającego się przedsiębiorstwa. Do prac nad rozbudową-kreacją nowej kawiarni zatrudniony został włoski architekt Francisco Terencio Gianotti. Stara kawiarnia znajdowała się dokładnie na rogu Avenida Rivadavia i Avenida Callao (i tak miało pozostać), ale właściciel, planując rozszerzenie przedsiębiorstwa, kupił sąsiednie działki wraz z mieszczącą się na nich zabudową. Brenna wyznaczył architektowi zadanie, by ten, nie zamykając funkcjonującej cały czas kawiarni, rozbudował dotychczasową siedzibę cukierni

${ }^{39}$ Cukiernia, kawiarnia, miejsce, gdzie zazwyczaj zarówno produkuje się, jak i sprzedaje własne wyroby cukiernicze. 

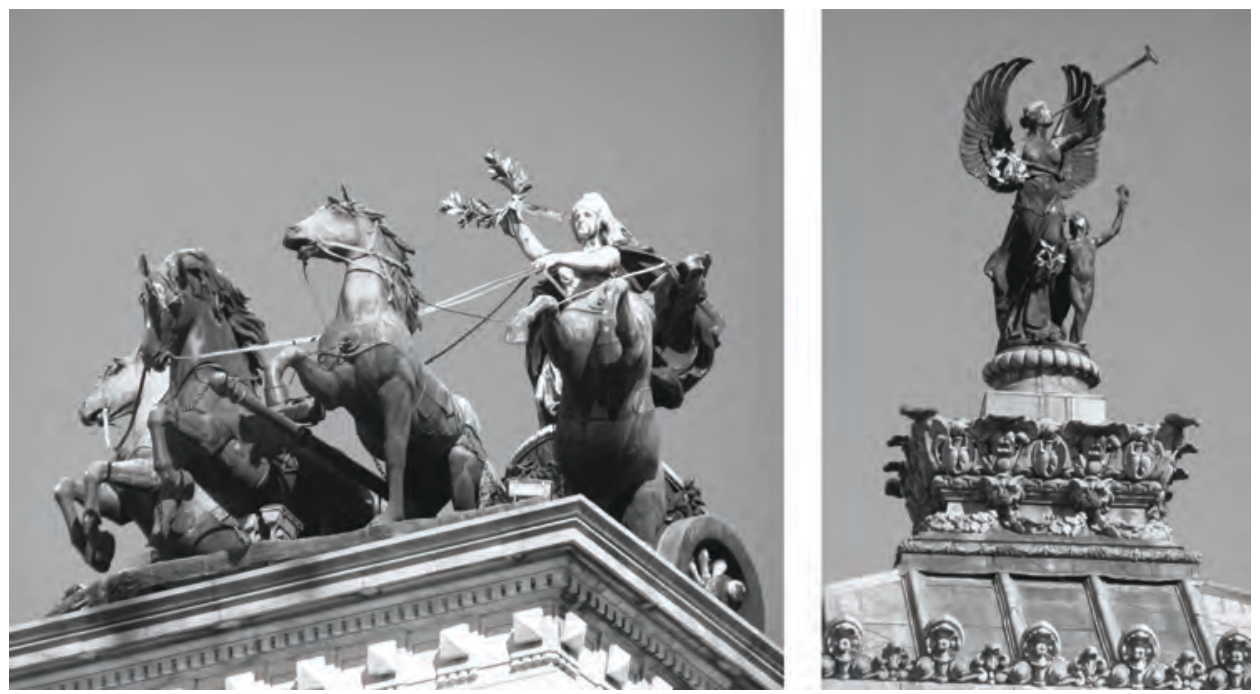

Ryc. 63. Dekoracja rzeźbiarska Palacio del Congreso, 1897-1906, arch. Vittorio Meano, 2008

- udało się tego dokonać w ciągu roku. Obecny (do niedawna jeszcze użytkowany gmach) posiada trzy kondygnacje podziemne i parter z konstrukcją wzmocnioną elementami żelaznymi oraz pięć żelbetowych pięter ${ }^{40}$. Ze względu na formę najbardziej charakterystyczne dla budynku jest zwieńczenie narożnika ozdobione ażurową strukturą wiatraka. Losy tego fantazyjnego obiektu, prosperującego świetnie przez prawie całe stulecie, są dziś smutne - stoi opuszczony, bez gospodarza i opiekuna. Angel Castro w artykule z 22 grudnia 2012 r. skarży się na łamach „La Nación” na decydentów miasta, że w swej głupocie są w stanie „porzucić” taki skarb, jakim jest dla Buenos Aires El Molino. Pisze o umierającym budynku, o opustoszałych biurach, wyprzedaży pomieszczeń (a szczególnie wielkiego, reprezentacyjnego salonu na pierwszym piętrze, który sporadycznie wykorzystywany był już tylko jako przestrzeń ekspozycyjna książek) i wreszcie o zamknięciu baru będącego przez lata wizytówką dzielnicy, a może i miasta. Mimo że kilka lat temu powstał projekt zapisany na „poziomie narodowym”, ażeby przywrócić świetność temu miejscu i „odzyskać” je dla miejskiej społeczności - budynek El Molino został ogłoszony Historycznym Zabytkiem Narodowym - losy obiektu są nadal niepewne. Pierwszy projekt szybko porzucono sin pena ni gloria (bez żalu czy chwały) i został zastąpiony w połowie 2006 r. przez inny. To, co wydaje się niepokojące, to plany pozbawienia budynku jego dotychczasowej funkcji. „Reformatorzy” zdają się zapominać, że nie tylko skorupa

40 S. Kiernan, Por la vuelta de El Molino, „Pagina 12”, 7.02.2009; http://www.pagina12.com. ar/diario/suplementos/m2/10-1576-2009-02-07.html (dostęp: 15.11.2012). 
architektoniczna stanowi o dziedzictwie kulturowym, lecz równie istotne jest funkcjonowanie na tym rogu kawiarni, jej istnienie jest tak samo ważne, jak istnienie samego budynku. Dziś El Molino widzi się raczej jako centrum wydarzeń kulturalnych, miejsce różnego rodzaju imprez, konferencji, ekspozycji ${ }^{41}$. Jednak we wrześniu $2012 \mathrm{r}$. gmach pozostawał zamknięty i nic nie wskazy wało na to, by w najbliższym czasie sytuacja ta miała ulec zmianie.
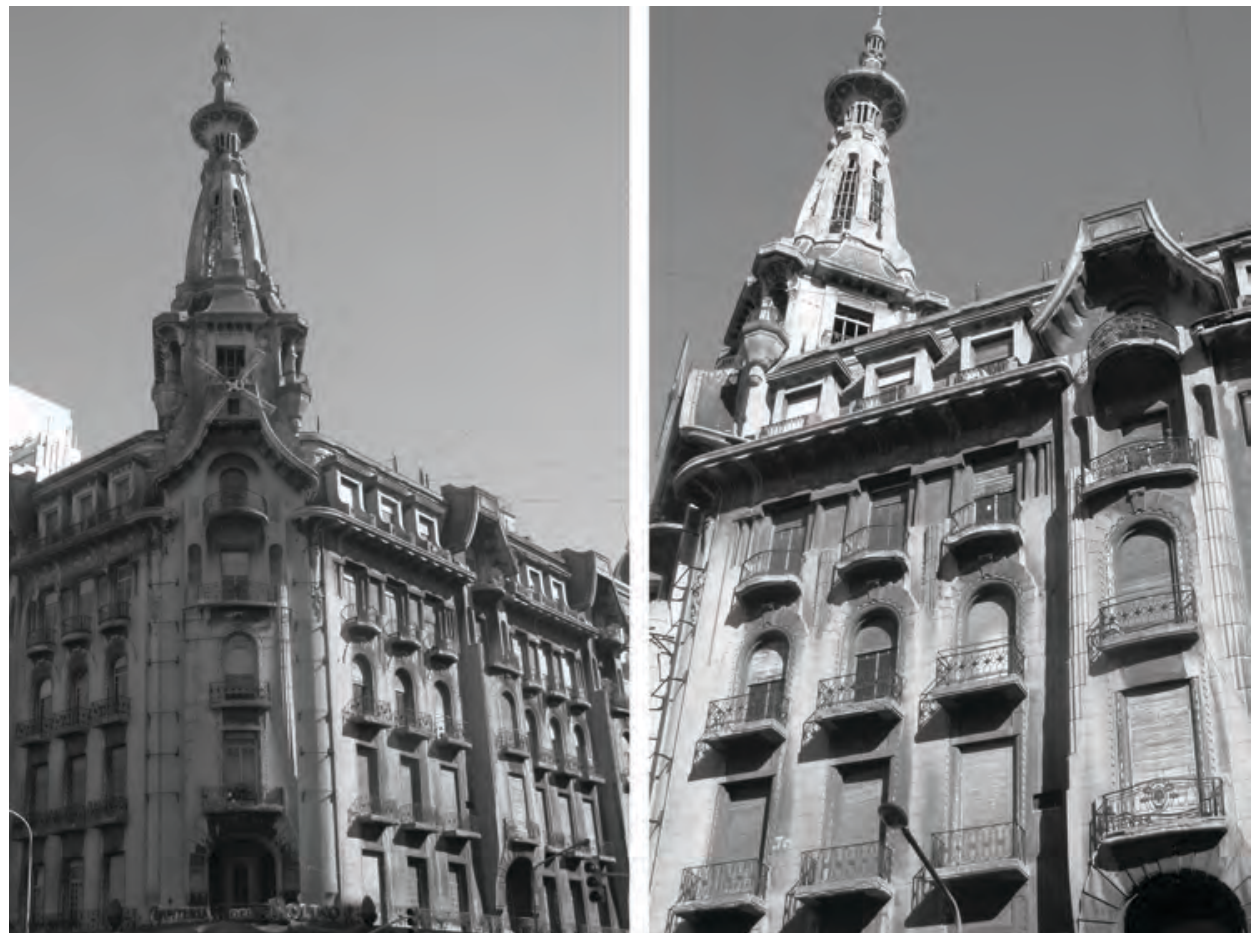

Ryc. 64. Budynek dawnej La Confitería Molino, 1916, Francisco Terencio Gianotti, Buenos Aires, 2008

Również w dość bliskim sąsiedztwie Palacio del Congreso znajduje się kolejny ciekawy obiekt architektoniczny Buenos Aires - Palacio Barolo. Budynek zlokalizowany jest przy Avenida de Mayo, przecznicę od Plaza del Congreso. Jak pisze Ramón Gutiérrez, możemy go traktować jako przykład „wyczucia monumentalizmu we włoskim rozumieniu”42, co autor wiąże z postacią projektanta i architekta budowli Maria Palantiego. Rzeczywiście w momencie wznoszenia był jednym z najwyższych obiektów w Buenos

${ }^{41}$ S. Kiernan, op. cit.; A. Castro, Buscan salvar la Confitería del Molino, http://www. lanacion.com.ar/1434672-buscan-salvar-la-confiteria-del-molino (dostęp: 15.11.2012).

${ }^{42}$ R. Gutiérrez, op. cit., s. 546. 
Aires. Inwestycje finansował włoski milioner Luis Barolo, który przybył do Ameryki w 1890 r. Założył pierwszą w Argentynie przędzalnię bawełny, a następnie plantację bawełny w regionie Chaco. Projekty Palacio Barolo powstały w 1919 r., a inauguracja budynku miała miejsce 7 lipca 1923 r. - niestety inwestor nie doczekał oficjalnego ukończenia prac, zmarł bowiem rok wcześniej. Podczas uroczystości otwarcia obiektu, nowoczesnego jak na ówczesne Buenos Aires, w bardziej tradycyjnym duchu został on poświęcony przez nuncjusza apostolskiego Giovanniego Bedę Cardinalego.
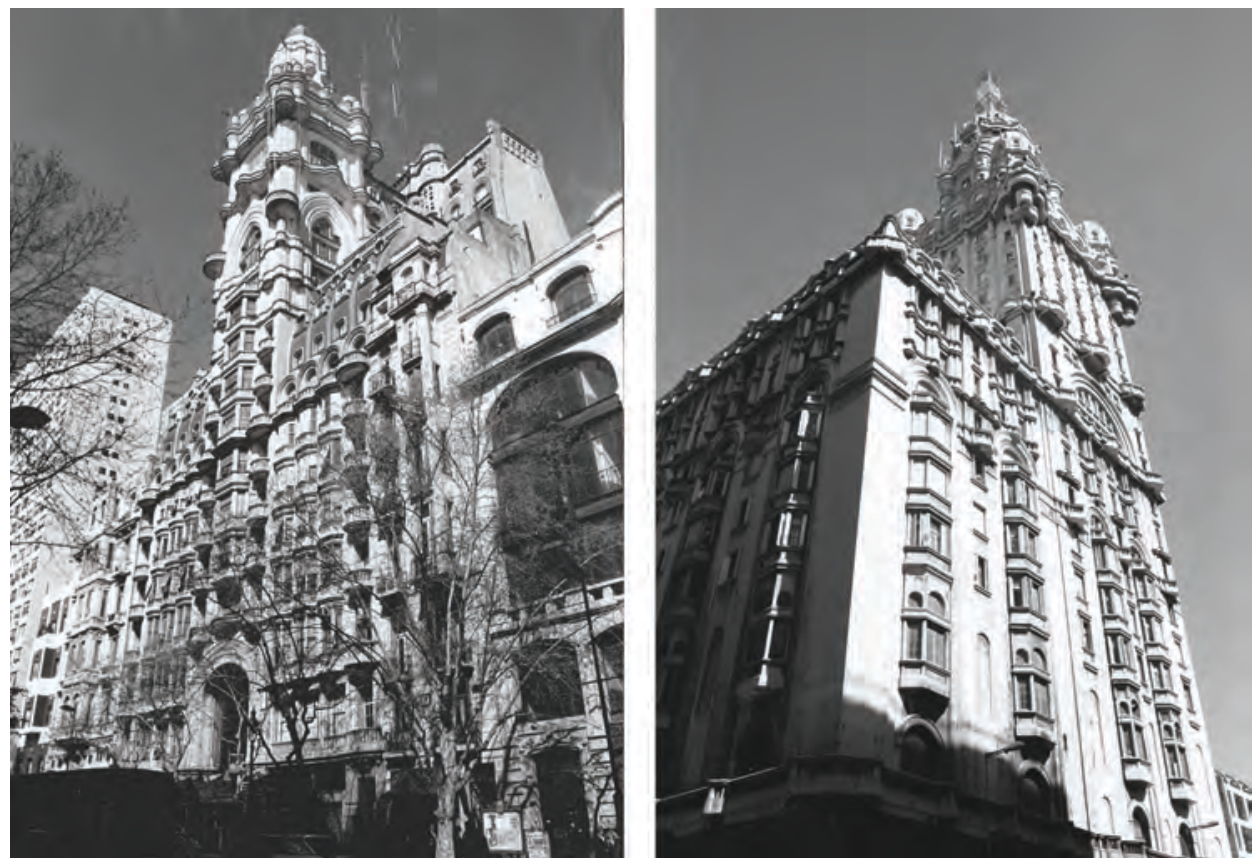

Ryc. 65. Palacio Barolo, 1923, Buenos Aires, Palacio Salvo, 1922-1925, Montevideo, Mario Palanti, 2004

Budowla przypomina inną realizację wykonaną według projektu Maria Palantiego - Palacio Salvo w Montevideo (1922-1925). Jednakże, podczas gdy urugwajski budynek przeznaczony był głównie na cele hotelowe oraz handlowe w najniższych kondygnacjach, Palacio Barolo był przede wszystkim biurowcem. Oczywiście, jak w większości budynków przy Avenida de Mayo, na dole znalazły się pasaże handlowe, restauracja i sale spotkań. Palanti zaprojektował gmach aż po najmniejsze detale, od wnętrz kabin w windach po elementy metalowe, jak poręcze i okratowania, nawet lampy wykonano według jego rysunków. Podobno był bardzo przywiązany do swego dzieła, krąży nawet anegdota mówiąca o tym, że w miejskich archiwach nie ma 
planów architektonicznych Palacio Barolo, ponieważ M. Palanti nie mógł się z nimi rozstać i zabrał je, wracając do Europy. Dziś przestrzenie biurowe zajmowane są głównie przez kancelarie adwokackie, oficyny wydawnicze i pracownie architektoniczne ${ }^{43}$.

Podobnie jak w architekturze Buenos Aires dominuje eklektyzm, tak struktura narodowościowa artystów tworzących architektoniczny krajobraz miastajest niezwykle zróżnicowana. Wśród działających wstolicy architektów odnaleźć można m.in. Włochów (M. Palanti' ${ }^{44}$, F. Tamburini, Vilvente Colmegna), Szwedów (K. Kihlberg), Norwegów (O. Boye, A. Christophersen), Francuzów (Emilio Hugè) czy Anglików (E. Taylor). Ten ostatni był twórcą budynku Adauna Nueva. W swoich dziełach wznoszonych w argentyńskiej stolicy poprzez wprowadzanie kolumnad w monumentalnym porządku nawiązywał do dzieł londyńskiego architekta Charlesa Barry'ego ${ }^{45}$.

\section{POLSKIE ŚLADY W BUENOS AIRES}

Na a przełomie wieków w Buenos Aires pracowało niewielu polskich artystów. Dziś pamięta się przede wszystkim inżynierów i budowniczych dróg kolejowych. Do tej grupy należał Czesław Jordan Wysocki, który poza pracami typowo inżynieryjnymi podjął się także organizacji jednego z ważniejszych parków Buenos Aires. Inżynier brał udział w projektowaniu obszaru zieleni w modnej obecnie dzielnicy Palermo, nazywanego Parque Tres de Febrero albo Bosque de Palermo. W pracach pomagali mu inni Polacy: Michał Górski, Wiktor Woyniłłowicz i Julian Bielewicz ${ }^{46}$.

Oczywiście różnorodność narodowa przełomu wieków odnosiła się nie tylko do sztuki, pozostałe strefy życia także były kontrolowane przez wielonarodowe społeczeństwo, a pewne gałęzie handlu, przemysłu, interesów stawały się domeną określonych nacji. Polscy i rosyjscy Żydzi zdobyli sobie w tym okresie w Buenos Aires sławę jako właściciele domów publicznych. Przedsiębiorstw niezwykle znanych i popularnych. Mowa tu o czasach pomiędzy $1875^{47}$ a $1936 \mathrm{r}$. Pierwsza data odnosi się do legalizacji prostytucji w Argentynie ${ }^{48}$, druga zaś związana z ograniczeniem jej funkcjonowania ${ }^{49}$.

${ }^{43}$ J. Solsona, C. Hunter, La avenida de Mayo. Un proyecto inconcluso, Buenos Aires 1990, s. 84-85.

${ }^{44}$ E. Gutiérrez, op. cit., s. 546-547.

${ }^{45}$ Urodził się w Chelsea w 1801 r., przyjechał do Buenos Aires, gdzie pracował jako architekt (H.S.J. Panda, op. cit., s. 113).

${ }^{46}$ M. Bryszewska, J. Gmitruk, J. Mazurek, Wstęp, [w:] Polonia w piśmiennictwie polskim. Antologia, oprac. M. Bryszewska, J. Gmitruk, J. Mazurek, Buenos Aires-Warszawa 2004, s. 13-14.

47 A.M. Carretero, Prostitución en Buenos Aires, Buenos Aires 1995, s. 26-30.

48 Przepis porządkujący „prostytucję” w Argentynie znany jest jako Reghlamento sobre prostitución, pochodzi z 5.01.1875 r. (A.M. Carretero, op. cit., s. 235-239).

${ }^{49}$ Ibidem, s. 170-171. 

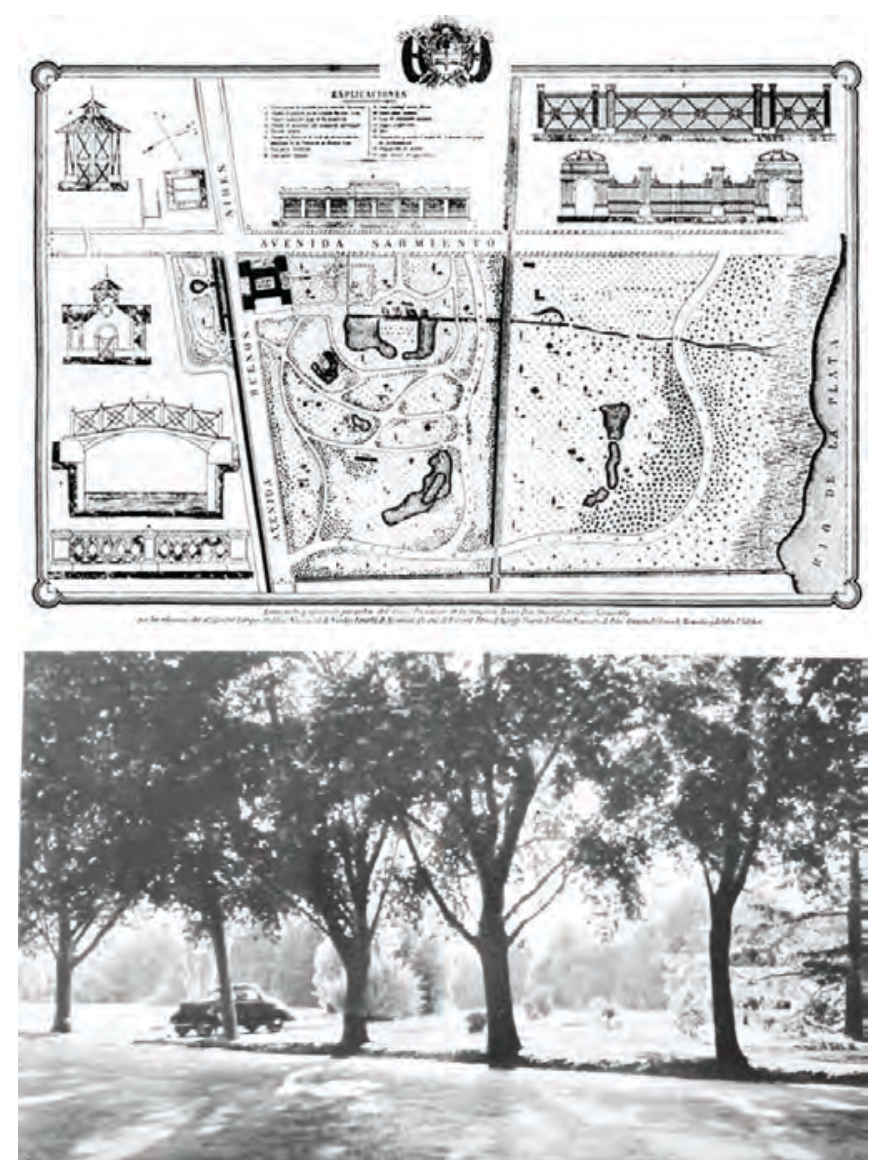

Ryc. 66. Park Tres de Febrero (Bosque de Palermo), plan i widok

Żydzi, w większości polscy i rosyjscy, 7 maja 1906 r. założyli w Buenos Aires Towarzystwa Izraelskie Wzajemnej Pomocy „Warszawa”, choć przedsięwzięcie przygotowywane było jeszcze w latach dziewięćdziesiątych XIX w. ${ }^{50}$ Instytucja założona przez właścicieli domów publicznych miała znamiona organizacji o charakterze dobroczynnym, w statucie istniał zapis o nienagannej reputacji jej członków ${ }^{51}$. Tymczasem członkowie towarzystwa w rzeczywistości parali się handlem żywym towarem, zarządzając większością ówczesnych domów publicznych w Buenos Aires, i faktycznie wzajemnie wspierali się $\mathrm{w}$ tym procederze. Organizacja z czasem zmieniła nazwę na „Zwi Migdal”. Handel kobietami i powiązania tego procederu z Ameryką

${ }^{50}$ G. Bra, La organización negra. La increíble historia de la Zwi Migdal, Buenos Aires, 1999, s. 30.

${ }^{51}$ Ibidem, s. 31. 


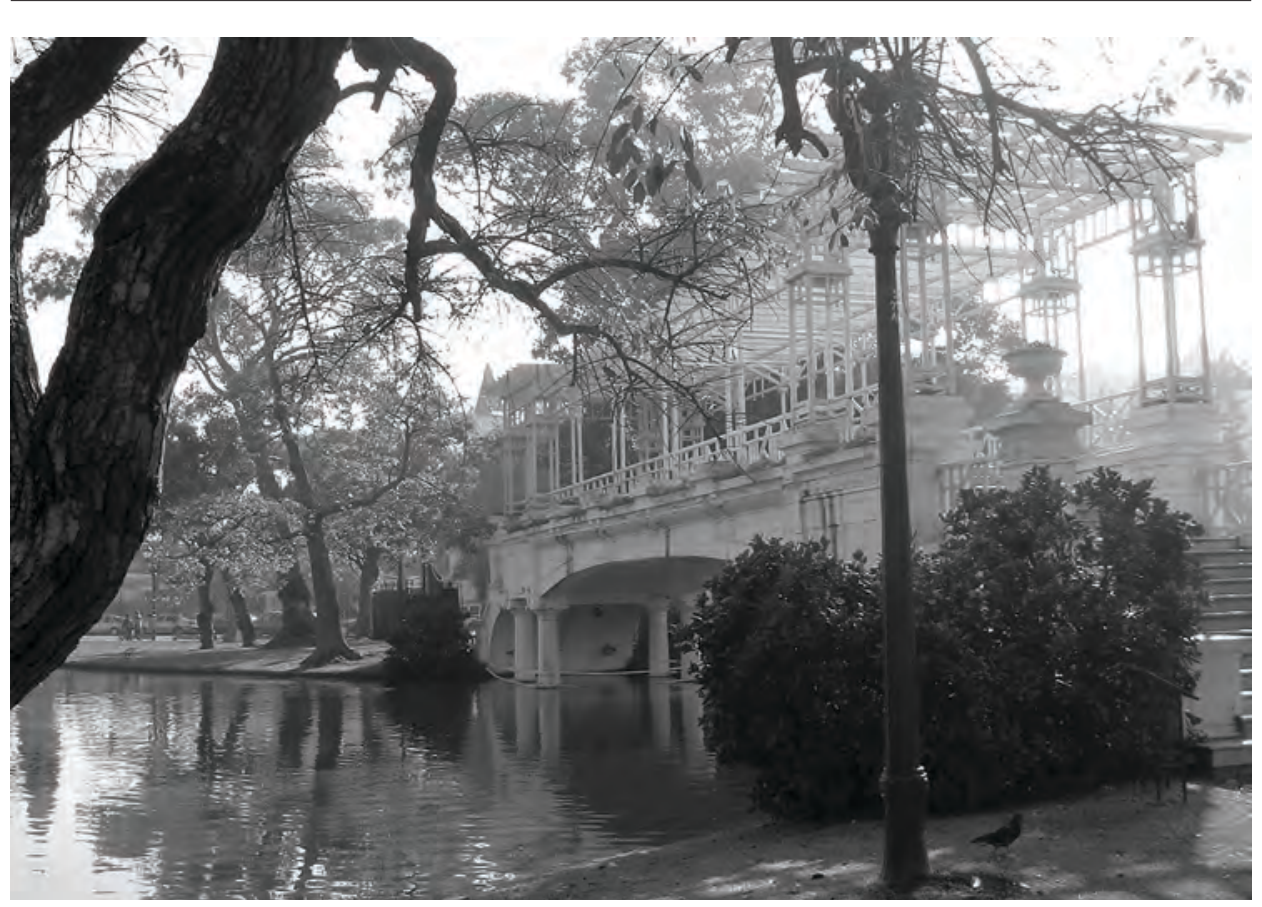

Ryc. 67. Park Tres de Febrero (Bosque de Palermo), widok współczesny, 2011

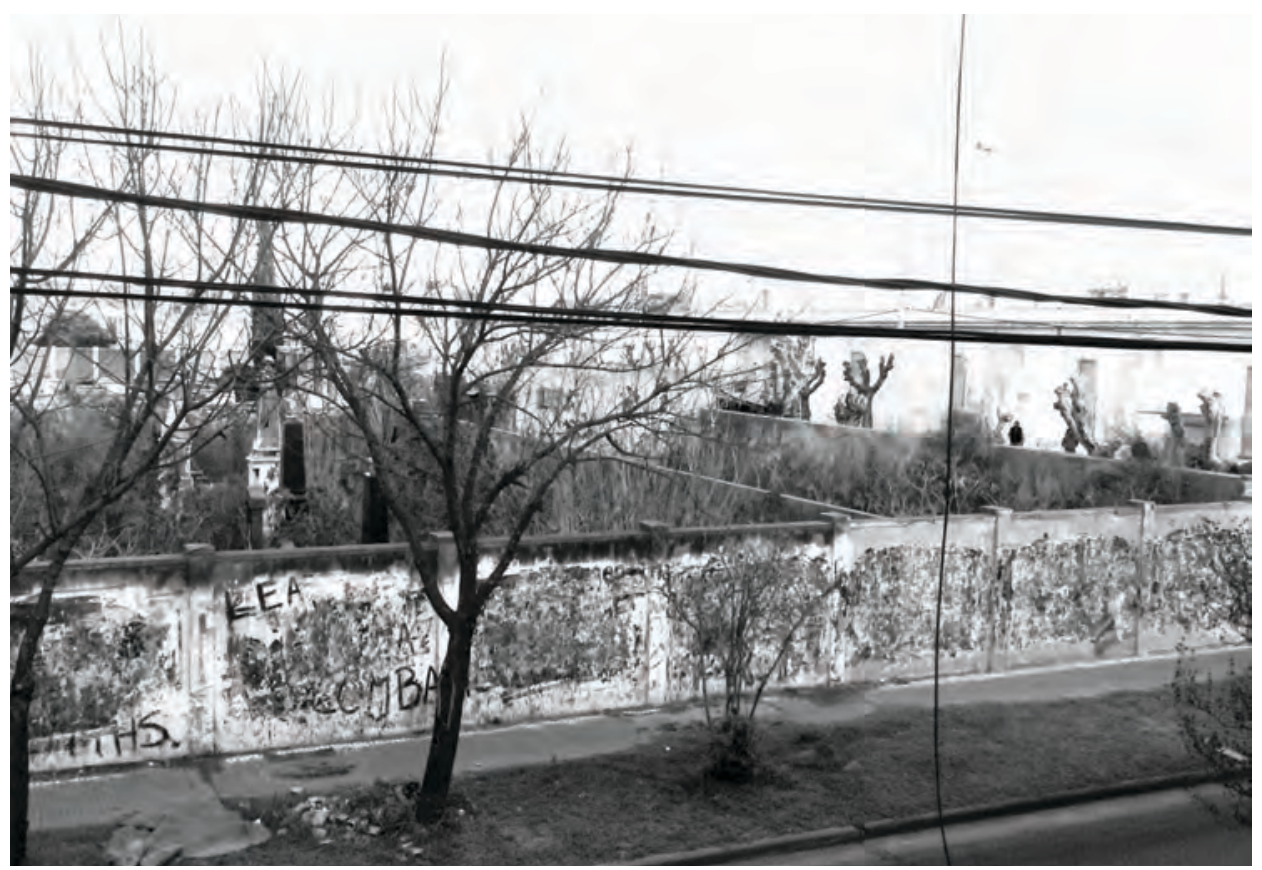

Ryc. 68. Cmentarz żydowski - Cementerio Rufián, Avellaneda, Buenos Aires 
Południową znalazło odwierciedlenie w zarówno w polskiej prasie codziennej, jak i w komentującej ówczesną rzeczywistość twórczości artystycznej. W warszawskim „Naszym Przeglądzie” z 28 czerwca 1930 r. czytamy:

„Varsovia” posiada w Buenos Aires piękny budynek w stylu pałacowym. Mieści się w nim synagoga i sala zabaw, przed jego bramą zawsze rzędy pięknych samochodów, wszystko zgrabnie maskuje prawdziwą istotę stowarzyszenia. Mimo to ludność żydowska w Buenos Aires i kolonia polska zawsze była dobrze poinformowana o prawdziwych celach tego towarzystwa, bojkotowano jego członków do tego stopnia, że musieli sobie założyć własny cmentarz, wymuszono na nim w 1927 r., by zmieniło nazwę i nie hańbiło imienia Warszawy. Wówczas przechrzciło się na Cwi Migdał ${ }^{52}$.
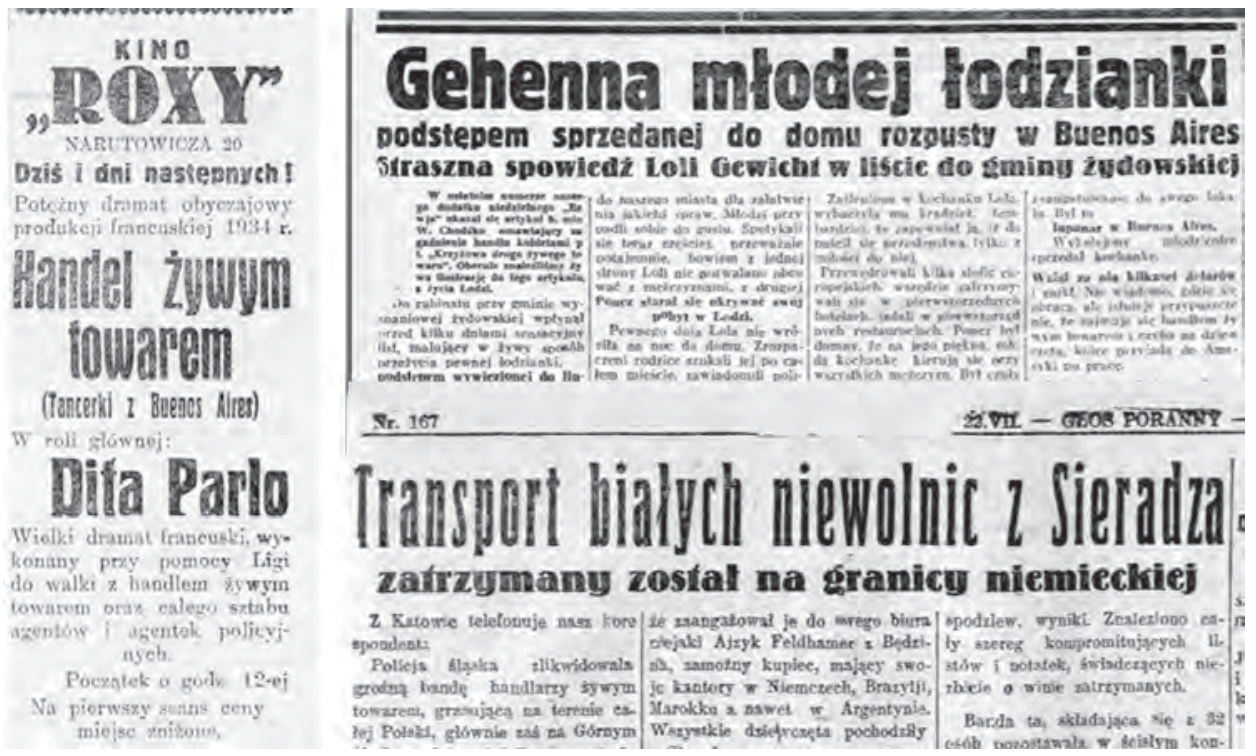

Ryc. 69. Reklama filmu francuskiego Handel żywym towarem (1934),

nagłówki artykułów Gehenna młodej łodzianki i Transport białych niewolnic z Sieradza

W łódzkim "Głosie Porannym” (nr 167 z 1929 r. i nr 299 z 1935 r.) ${ }^{53}$ opublikowano dwa krótkie artykuły dotyczące wspomnianego problemu. Pierwszy z nich zatytułowany został Transport białych niewolnic z Sieradza i dotyczy zatrzymania grupy dziewcząt z fałszywymi paszportami, które miały być sprzedane do domów publicznych Ameryki Południowej. Osobą odpowiedzialną za wspomniany proceder był Ajzyk Feldhamer z Będzina,

52 A. Sofer, Cwi Migdał, „Nasz Przegląd” 1930, R. 7, nr 179 (2618), s. 4.

${ }^{53}$ Za pomoc w odnalezieniu materiałów źródłowych chciałabym podziękować dr Irminie Gadowskiej. 


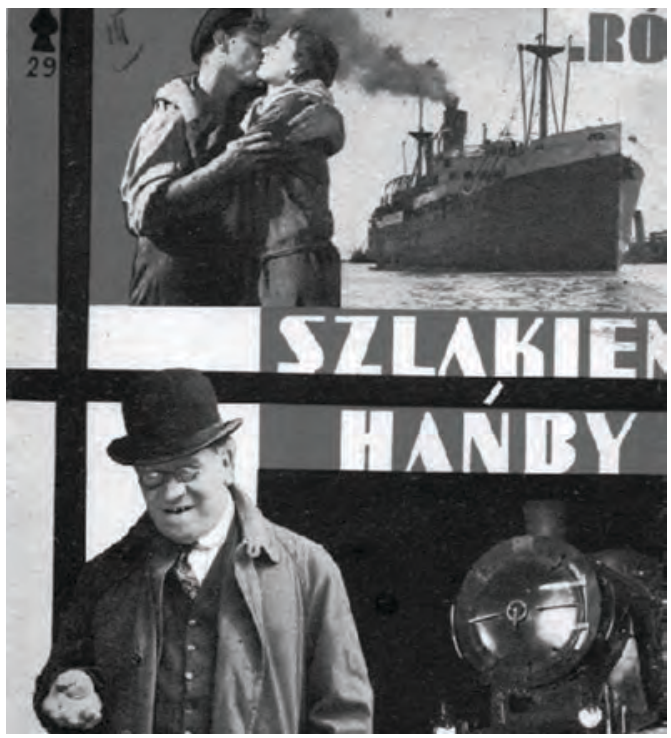

Ryc. 70. Fragment okładki książki Antoniego Marczyńskiego, Szlakiem hańby, 1930

który mając swoje kantory w Maroku, Brazylii i Argentynie, zaopatrywał jednocześnie tamtejsze domy publiczne $\mathrm{w}$ dziewczęta pochodzące $\mathrm{z}$ Polski. Banda zajmująca się handlem liczyła 82 osoby, a każda z kobiet sprzedawana była za kwotę od 20 do 80 dol. ${ }^{54} \mathrm{~W}$ drugim artykule zaprezentowana została historia mieszkanki Łodzi czyli Gehenna młodej łodzianki podstępem sprzedanej do domu rozpusty w Buenos Aires. Straszna spowiedź Loli Gewicht w liście do gminy żydowskiej. Dziewczyna został uwiedziona przez mieszkającego w Sieradzu Ignacego Poncza. Mężczyzna ograbił swojego szefa, a następnie, korzystając z gotówki, zabrał dziewczynę za granicę, gdzie „przewędrowali kilka stolic europejskich, wszędzie zatrzymywali się w pierwszorzędnych hotelach". Gdy dotarli do Buenos Aires, fundusze się skończyły. Kochanek, niezdolny do regularnej pracy, coraz gorzej traktował Lolę, wreszcie sprzedał dziewczynę do domu publicznego, zyskując na tej transakcji kilkaset dolarów, i zniknął. Kobieta próbowała skontaktować się z rodziną - ta jednak w międzyczasie zmieniła miejsce zamieszkania - wreszcie wysłała list do gminy żydowskiej z prośbą o pomoc ${ }^{55}$.

Ta i podobne historie stały się źródłem dla opowieści wykreowanej przez Antoniego Marczyńskiego pt. Szlakiem hańby, która najpierw została zekranizowana (1929), a następnie doczekała się publikacji książkowej zrealizowanej przez Towarzystwo Wydawnicze „Rój” (1930). Problem handlu kobietami był także popularny za granicą. W $1931 \mathrm{r}$. został nakręcony film Tänzerinnen für Süd-Amerika gesucht (Ameryka Południowa poszukuje tancerek) z udziałem Dity Parlo (Polki z pochodzenia). Wyświetlany go także w łódzkich kinach - wzmianki na ten temat odnajdujemy w ówczesnej prasie, na łamach „Głosu Porannego" 56 , czy „Republiki”"57.

54 Transport białych niewolnic z Sieradza, „Głos Poranny” 1929, nr 167, s. 5.

${ }_{55}$ Gehenna młodej łodzianki podstępem sprzedanej do domu rozpusty w Buenos Aires. Straszna spowiedź Loli Gewicht w liście do gminy żydowskiej, „Głos Poranny”, nr 299 (1935), s. 8.

${ }^{56}$ Handel żywym towarem, "Głos Poranny” 1935, nr 108, s. 8.

57 Tancerka z Buenos Aires. Handel żywym towarem, „Republika”, nr 96, 9.IV.1934, s. 2. 

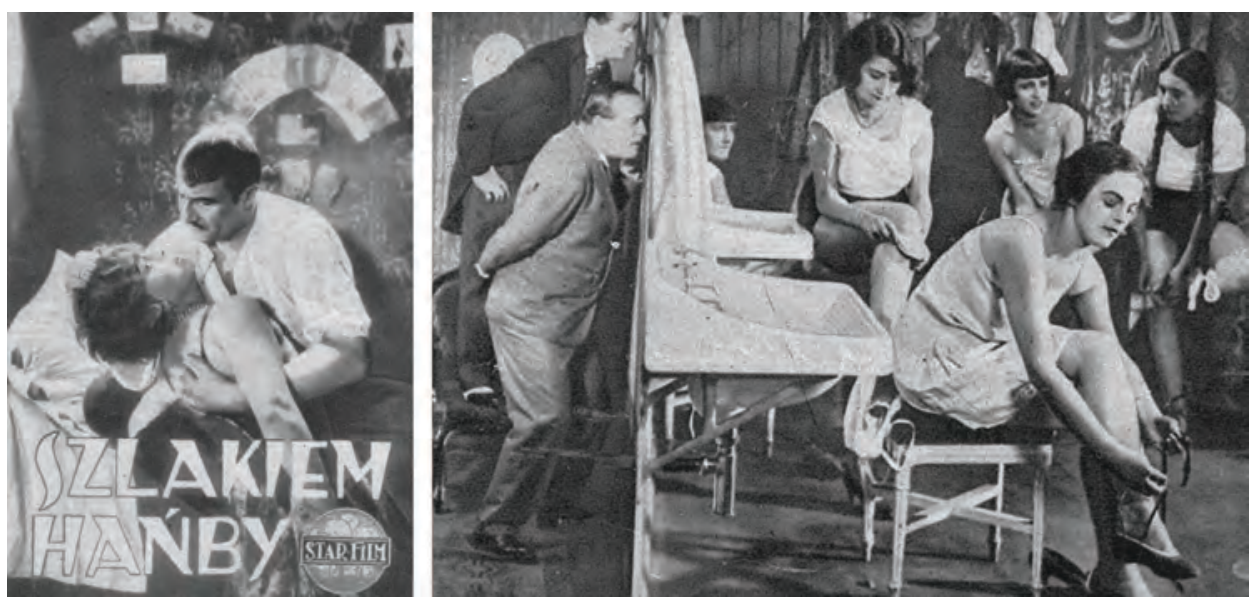

Ryc. 71. Plakat filmowy i kadr z filmu, Szlakiem hańby, 1929

\section{NA ZAKOŃCZENIE WRACAJĄC DO AMERYKI}

Kosmopolityzm w architekturze był materialnym odzwierciedleniem Kkreacji nowego miasta - Buenos Aires powstające na podobieństwo metropolii europejskich miało być miastem „światłym i cywilizowanym” w kontraście do „barbarzyńskich form”, które odnaleźć można było w codziennym, tradycyjnym życiu prowincji ${ }^{58}$. Buenos Aires śniło o Europie, o wielkości dalekich metropolii, jednak nigdy, ze względu na swoje położenie, nie mogło stać się miastem prawdziwie europejskim. Najbardziej niepokojącym elementem, który można zauważyć w procesie europeizacji Argentyny, jest zerwanie na ponad wiek z tradycją i kolonialnymi korzeniami. Zdecydowana negacja czasów dominacji hiszpańskiej trwała bardzo długo, dopiero w latach dwudziestych XX w. rozpoczął się proces powolnej akceptacji przeszłości. W 1918 r. grupa architektów zaproponowała rewizję oceny architektury i sztuki okresu kolonii hiszpańskiej. Oczywiście nowe spojrzenie miało związek z ogólnie rozwijającymi się tendencjami w literaturze, ideami popularnymi wśród inteligencji - było związane z narodzinami pierwszej generacji nacjonalizmu argentyńskiego. Jednak po tak długim czasie trudno było wyróżnić cechy prawdziwie „lokalne”, w architekturze miejscowy styl kolonialny mieszał się z Californian Mission Style, a hiszpańskość przejawiała się w swoistej malowniczości postkolonialnych realizacji ${ }^{59}$. Jednak poszukiwania własnych korzeni i odkrywanie przeszłości trwają, dziś mieszkańcy Ameryki Południowej mają coraz większe poczucie wartości własnego dziedzictwa. Obecnie, jak pisze Marshall C. Eakin:

${ }^{58}$ Gutiérrez, op. cit., s. 391.

${ }^{59}$ F. Ortiz, op. cit., s. 133. 
Ameryka Łacińska stała się poważnym „eksporterem” kultury. Czasy, gdy latynoamerykańskie elity ślepo naśladowały Europejczyków jako twórców wszelkich wartości kulturowych, minęły bezpowrotnie ${ }^{60}$.

Jednak w przypadku Argentyny, a szczególnie Buenos Aires, sytuacja nie jest tak do końca jednoznaczna. W tym zeuropeizowanym mieście żyją ludzie nadal zawieszeni pomiędzy Starym i Nowym Światem. Gdy pytamy ich o narodowość, większość bez wahania potwierdza argentyńskie obywatelstwo, jednak prawie zawsze pojawia się „ale...”, po którym następuje poszukiwanie europejskich korzeni i wyliczanie dłuższe bądź krótsze - „moja babcia była Włoszką, moi dziadkowie przyjechali z Anglii, mama jest Argentynką ale tata Hiszpanem..." Buenos Aires jest miastem wielokulturowym, mieszanką narodowości, lecz także miastem z pewnym elementem niepewności, ze społeczeństwem zawieszonym w swoim poczuciu tożsamości między Ameryką, do której przynależy, i Europą, za którą nadal tęskni.

\section{BIBLIOGRAFIA}

Arquitectura Latinoamericana en el siglo XX, red. R. Gutiérrez, Barcelona 1998.

Aslan L., Novoa G., Buenos Aires: Balvanera, 1817-1970, Buenos Aires 1992.

Bra G., La organización negra. La increíble historia de la Zwi Migdal, Buenos Aires 1999.

Bryszewska M., Gmitruk J., Mazurek J., Wstęp, [w:] Polonia w piśmiennictwie polskim. Antologia, oprac. M. Bryszewska, J. Gmitruk, J. Mazurek, Bunos Aires-Warszawa 2004, s. 9-44.

Buschiazzo M.J., La arquitectura en la Republica Argentina 1810-1930, Buenos Aires 1966.

Carretero A.M., Prostitución en Buenos Aires, Buenos Aires, 1995.

Castro A., Buscan salvar la Confitería del Molino, http://www.lanacion.com.ar/1434672 -buscan-salvar-la-confiteria-del-molino (dostęp: 15.11.2012).

Daughton J.P., When Argentina Was „French": Rethinking Cultural Politics and European Imperialism in Belle-Époque Bienos Aires, „The Journal of Modern History”, grudzień 2008, nr 80, s. 831-864.

Drucaroff E., Piekło obiecane, Kraków 2010.

Eakin M.C., Historia Ameryki Łacińskiej. Zderzenie kultur, Kraków 2007.

Gehenna młodej łodzianki podstępem sprzedanej do domu rozpusty w Buenos Aires. Straszna spowiedź Loli Gewicht w liście do gminy żydowskiej, „Głos Poranny” 1935, nr 299, s. 8.

Gombrowicz W., Dziennik 1953-1969, Kraków 2011.

Gombrowicz W., Wspomnienia polskie. Wędrówki po Argentynie, Kraków 2011.

Guillén M.F., Modernism without Modernity: The Rise of Modernist Architecture in Mexico, Brazil, and Argentina, 1890-1940, "Latin American Research Review" 2004, t. 39, s. 6-34.

${ }^{60}$ M.C. Eakin, op. cit., s. 278. 
Gutiérrez R., Arquirectura y urbanismo en Iberoamerica, wyd. 4, Madrid 2002.

Handel żywym towarem, „Głos Poranny” 1935, nr 108, s. 8.

Kiernan S., Por la vuelta de El Molino, „Pagina 12”, 7.02.2009, http://www.pagina12.com.ar/ diario/suplementos/m2/10-1576-2009-02-07.html (dostęp: 15.11.2012).

Łepkowski T., Wojny o niepodległość (1801-1825), [w:] Dzieje Ameryki Łacińskiej 1750-1870/1880, t. 1, red. T. Łepkowski, Warszawa 1979, s. 145-278.

Łepkowski T., W poszukiwaniu kształtu niepodległości (1825-1870/80), [w:] Dzieje Ameryki Łacińskiej 1750-1870/1880, t. 1, red. T. Łepkowski, Warszawa 1979, s. 279-412.

Needell J.D., Rio de Janeiro and Buenos Aires: Public Space and Public Consciousness in Fin-DeSiècle Latin America, „Comparative Studies in Society and History”, lipiec 1995, t. 37, nr 3, s. 519-540.

Ortiz F., La arquitectura en la Argentina desde 1880 hasta 1930, seria „Arquitectura en Argentina", t. 8, Buenos Aires 1980.

Panda H.S.J., Arquitectura de 1850 a 1850, seria „Arquitectura en Argentina”, t. 7, Buenos Aires 1980.

Radovanovic E., Buenos Aires. Avenida de Mayo, Buenos Aires 2002.

Radovanovic E., Buenos Aires. Ciudad Moderna 1880-1910, Buenos Aires 2002.

Sofer A., Cwi Migdat, „Nasz Przegląd” 1930, R. 7, nr 179, (2618), s. 4.

Solsona J., Hunter C., La avenida de Mayo. Un proyecto inconcluso, Buenos Aires 1990.

Stemplowski R., Stabilizacja i rozwój zależny (1870/1880-1910/1918). Kraje La Platy, [w:] Dzieje Ameryki Łacińskiej 1870/1880-1929, t. 2, red. R. Mroziewicz, R. Stemplowski, Warszawa 1979, s. 149-168.

Szemiński J., Schyłek epoki kolonialnej (1750-1800), [w:] Dzieje Ameryki Łacińskiej 17501870/1880, t. 1, red. T. Łepkowski, Warszawa 1977, s. 37-143.

Tancerka z Buenos Aires. Handel żywym towarem, „Republika” 1934, nr 96, s. 2.

Transport białych niewolnic z Sieradza, „Głos Poranny” 1929, nr 167, s. 5.

Vincent I., Ciała i dusze, Wrocław 2006.

\section{SUMMARY}

\section{It is not just about architecture. Buenos Aires - the "European" city of South America}

Buenos Aires at the turn of the $19^{\text {th }}$ and $20^{\text {th }}$ centuries was a remarkable city, and its image was changing very quickly. It has had a distinctly "European" character, which is strongly present today. "Europeanisation" of the metropolis can be observed in urban planning of the city, organization of the streets and squares, in architectural robes of individual buildings, which was connected both with generally prevailing fashion, artistic trends, and the artists' origin, as well as the socio-political changes throughout the country. Various nationalities contributed to creation of the image of cultural Buenos Aires: French, Italians, British, Belgians, Scandinavians, and (to a lesser extent) Poles. The city has been compared to the "Promised Land", others have described it as the hell on earth. Its fame has continued to this day. The article aims at showing Buenos Aires in the late $19^{\text {th }}$ century and the first half of the $20^{\text {th }}$ century, presenting its architecture by discussing some of the most characteristic buildings and conveying the atmosphere of decadence, which it has been famous for. 